\title{
TREATMENT OF TANNERY EFFLUVIUM BY USING RADIANT-FENTON OXIDATION REACTOR
}

\section{SAMPATHKUMAR. V, JOTHI LAKSHMI. N, MANOJ. S, GOWRISHANKAR. K S, AJITH KUMAR. D, ASHOKVARADHAN. R \& CHANDRU. $K$}

Faculty Members of Civil Engineering Department, Kongu Engineering College, Perundurai, Erode, India

Bachelor's Degree in Civil Engineering, Kongu Engineering College, Perundurai, Erode, India

Tannery industry is one of the forebearer industries in the world The tanning process aims to transfigure skins in stable and non-perishable products namely leather.It is recognized as a serious environmental threat due to high chemical levels including salinity, organic loading (chemical oxygen demand or load, biological oxygen demand),inorganic, dissolved, suspended solids, ammonia, total nitrogen chromium chloride, sodium and other salt residues. The aim of the study is to determine the treatment of the tannery wastewater by using Radiant-Fenton oxidation reactor. To study the characteristics of the sample tannery wastewater such as $\mathrm{pH}=10$, colour $=600, \mathrm{BOD}$ $=2066 \mathrm{mg} / \mathrm{l}, \mathrm{COD}=6200 \mathrm{mg} / \mathrm{l}, \mathrm{TSS}=1400 \mathrm{mg} / \mathrm{l}$, Turbidity = $785 \mathrm{NTU}$, Chloride $=1000 \mathrm{mg} / \mathrm{l}$ were analyzed Initially the treatment of tannery wastewater was carried out by Radiant-Fenton Oxidation Reactor at lab scale, the reactor having a volume of 2.35 litres with inner and outer dia of $2.54 \mathrm{~cm}$ and $5.08 \mathrm{~cm}$ fabricated with inner tube of height 1.5 feet and 2 feet with a breadth of $120 \mathrm{~mm}$ and $80 \mathrm{~mm}$ respectively with $U V$ visible of 36 watts. The organic loading rate of $0.3 \mathrm{~kg} / \mathrm{COD} / \mathrm{m}^{3}$ with a flow rate of $8.6 \mathrm{l} / \mathrm{min}$ were applied to reactor. With the HRT as $8 \mathrm{hrs}$, COD and TSS removal was taken to be influencing parameter. The Photon-Fenton Oxidation Reactor was operated for 8 hours and gets the final output as $C O D=700 \mathrm{mg} / \mathrm{l}, \mathrm{BOD}=200 \mathrm{mg} / \mathrm{l}$, colour =300, turbidity $=30 \mathrm{NTU}, \mathrm{TSS}=95 \%$, pH 5, Chloride 150 mg/l. It has achieved the maximum removal efficiency of $95 \%$.

KEYWORDS: Tannery wastewater, Photon-Fenton Oxidation Reactor, Hydraulic Retention Time (HRT), Biological Oxygen Demand (BOD), Chemical Oxygen Demand (COD), Total Suspended Solids (TSS) \& Total Dissolved Solids (TDS)
\end{abstract}

Received: Jun 07, 2020; Accepted: Jun 27, 2020; Published: Jul 13, 2020; Paper Id.: IJMPERDJUN2020312

\section{INTRODUCTION}

According to the India, about 1 to 2 million gallons of wastewater per day are generated by average dyeing facility in India, reactive and direct dyeing generating most of the wastewater. The tanning process aims to makeover the skins into stable and everlasting products namely leather. There are four main areas of sub-processes required to make finished leather, they are Beam house operation, Tanyard processes, Retanning and Finishing. Tannery industries generally causes pollutants which produce wide kind of high concentration toxic chemicals. It alters salinity, organic loading (chemical oxygen demand or load, biological oxygen demand), inorganic, dissolved, suspended solids, ammonia, total nitrogen chromium chloride, sodium and other salt residues of water sources [14]. Discharge of highly coloured dye effluents in natural water constitutes one of the most important problems of the surface water. Industrial dye, effluent is visible even at concentrations lower than $1 \mathrm{mg} / \mathrm{L}$. The treatment of tannery wastewater is difficult due to complex nature of the industry and the number of chemicals employed in the leather 
process [2]. The treatment of tannery wastewater is also very complex because the raw material processed and the intermediate products manufactured vary greatly in their nature and composition. There are many methods available to eliminate effluvium from water for instance ozonation process were used to remove calcitrant compound from effluvium [12]. Fenton process also avail to eliminate effluvium but removal efficiency was quite lesser [4]. Other oxidation methods were also faced the low efficiency rate [8]. Many technologies are there to breakdown the effluvium of tannery industries but their overall removal efficiency was lesser. Radiant-Fenton process is used to get more removal efficiency under various light sources [7]. It includes solar sources too [10]. Fe2+/H2O2 UV irradiation accelerates the production of highly reactive species mainly hydroxyl radicals ( $\mathrm{OH}-)$ [15]. An alternate pathway is through the generation of HO2-, Which also absorb the UV radiation of $254 \mathrm{~nm}$ wavelength and produce hydroxyl radicals [5]. It can oxidize organic compounds producing organic radicals $(\mathrm{R})$. It has potential to initiate chain oxidation process, factors that influence the efficiency of Radiant-Fenton process include initial colour intensity, $\mathrm{H} 2 \mathrm{O} 2 / \mathrm{Fe} 2+$ concentration were found [9]. Hence eliminating or reducing the wastage at the source of cleaner technological options of Radiant-Fenton process under UV irradiation was discussed.

\section{MATERIAL AND EXPERIMENTAL SETUPS}

\subsection{Sample Collection}

The effluent samples were collected from Rathinam tannery in Naripallam $\left(11^{\circ} 40^{\prime} \mathrm{W}\right.$ and $\left.77^{\circ} 65^{\prime} 03^{\prime \prime} \mathrm{E}\right)$. The effluent samples were collected from the all stages of tanning processing viz., soaking, liming, deliming, pickling, vegetable tanning and Retanning. The effluent was collected in polythene containers of 2.5 litres capacity and were brought to the laboratory with due care and was stored at $20^{\circ} \mathrm{C}$ for further analysis. Chemicals used for the analysis of spent liquor were analytical grade reagents. The physical and chemical characteristics of tannery effluents parameters viz. $\mathrm{pH}$, total alkalinity, total acidity, COD, BOD, total solids (TS), total dissolved (TDS), total suspended solids (TSS), chlorides and sulphides were analyzed as per standard procedures [3].

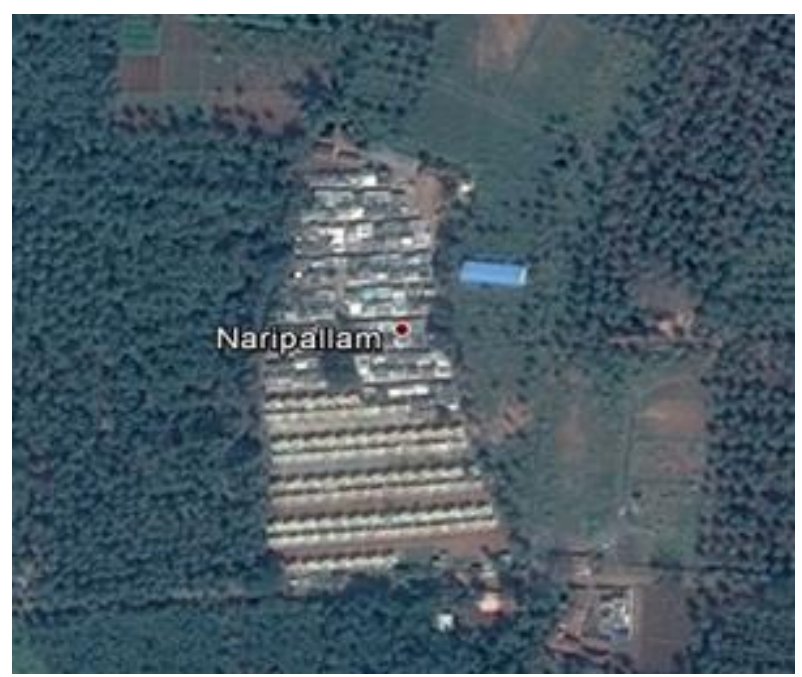

Figure 1: Study area location

\subsection{Experimental setup}

Photo Fenton Reactor with Inner and Outer tube of diameter $2.54 \mathrm{cmand} 5.08 \mathrm{~cm}$ respectively, connected with UV are used in the experiments [1]. It has a volume of 2.35 litres and fabricated with inner and outer tube of height 1.5 feet and 2 feet 
with a breadth of $120 \mathrm{~mm}$ and $80 \mathrm{~mm}$ respectively. The Experimental work was carried out in order to evaluate the removal efficiency of the COD and TSS. During the Experimental work the organic loading rate of $0.3 \mathrm{~kg} / \mathrm{COD} / \mathrm{m} 3$ with a flow rate of $8.6 \mathrm{l} / \mathrm{min}$ were applied to reactor with the HRT as $8 \mathrm{hrs}$, COD and TSS removal was taken to be influencing parameter. The process usually involves the use of low-pressure UV lamps with a principal wavelength of $254 \mathrm{~nm}$ [6][11]. Since the maximum absorption of ozone molecules is at $253.7 \mathrm{~nm}$. The light source commonly used is a medium -pressure mercury lamp wrapped in a quartz sleeve that can generate the UV light at wavelength of 200-280nm. They applied two different UV radiations $150 \mathrm{~W}, 15 \mathrm{~W}$ to the synthetic tannery effluvium. The performance of the Reactor was evaluated at HRT (HRT=V/Q); V-Reactor volume; Q-effluvium flow.

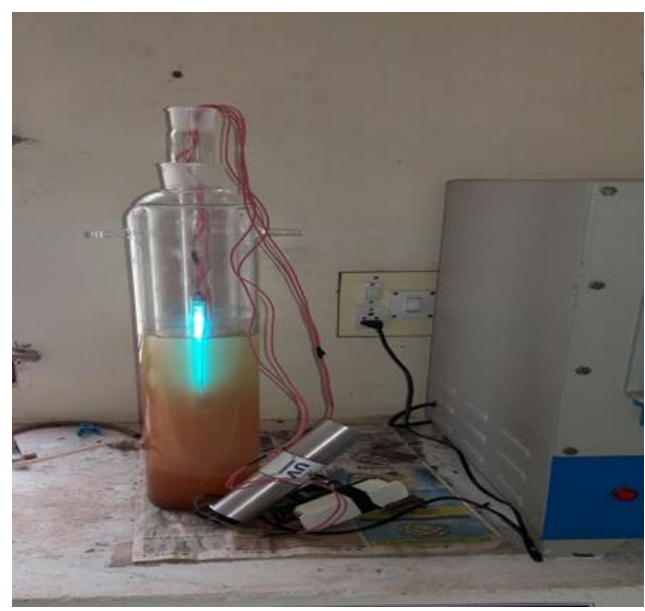

Figure 2: Effluvium treatment setup

\section{RESULT AND DISCUSSIONS}

\subsection{Removal of Cod}

The effect of $\mathrm{H}_{2} \mathrm{O}_{2}$ and $\mathrm{Fe}^{2+}$ dosage ranging from $5 \mathrm{ml}$ to $60 \mathrm{ml}$ to $2 \mathrm{gm}$ to $8 \mathrm{gm}$ on the removal of COD efficiency was investigated while stabilizing all the conditions of the reaction and altering the $\mathrm{H}_{2} \mathrm{O}_{2}$ and $\mathrm{Fe}^{2+}$ doses. With the HRT of 8 hrs., but at time of $4 \mathrm{hrs}$ it reaches a maximum removal efficiency of $74 \%$ at concentration of $4 \mathrm{gm}$ of $\mathrm{Fe}^{2+}$ and $20 \mathrm{ml}_{2} \mathrm{O}_{2}$.

Table 1: Removal Efficiency of COD for 8hrs

\begin{tabular}{|c|c|c|c|}
\hline Duration(hr.) & $\begin{array}{c}\text { Initial value } \\
\text { of COD } \\
(\mathbf{m g} / \mathbf{l})\end{array}$ & $\begin{array}{c}\text { Final } \\
\text { value of } \\
\text { COD } \\
\text { (mg/l) }\end{array}$ & $\begin{array}{c}\text { Removal } \\
\text { efficiency } \\
\text { of COD in } \\
\text { \% }\end{array}$ \\
\hline 1 & 1600 & 5428.57 & 12.44 \\
\hline 2 & 1600 & 3333.3 & 46.80 \\
\hline 3 & 1600 & 2900 & 53.22 \\
\hline 4 & 1600 & 1600 & 74.19 \\
\hline 5 & 1600 & 2100 & 66.18 \\
\hline 6 & 1600 & 2100 & 66.18 \\
\hline 7 & 1600 & 1123.9 & 45.46 \\
\hline 8 & 1600 & 1432 & 30.68 \\
\hline
\end{tabular}

There is no reaction during $5^{\text {th }}$ and $6^{\text {th }}$ hour of COD value but after that we can see reactions at low rate. This is shown in graph. 


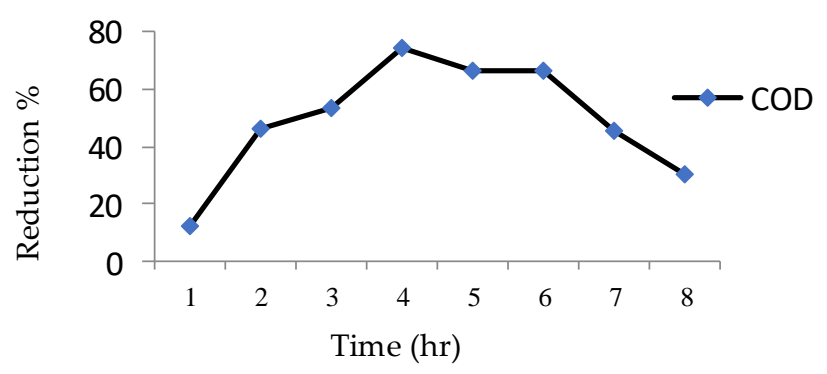

Figure 3: Graph of COD removal efficiency for $8 \mathrm{hrs}$.

\subsection{Removal of TSS}

The effect of $\mathrm{H}_{2} \mathrm{O}_{2}$ and $\mathrm{Fe}^{2+}$ dosage ranging from $5 \mathrm{ml}$ to $60 \mathrm{ml}$ to $2 \mathrm{gm}$ to $8 \mathrm{gm}$ on the removal of TSS efficiency was investigated while stabilizing all the conditions of the reaction and altering the $\mathrm{H}_{2} \mathrm{O}_{2}$ and $\mathrm{Fe}^{2+}$ doses.

Table 2: Removal Efficiency of TSS for $8 \mathrm{hrs}$

\begin{tabular}{|c|c|c|c|}
\hline Duration(hr.) & $\begin{array}{c}\text { Initial value } \\
\text { of COD } \\
(\mathbf{m g} / \mathbf{l})\end{array}$ & $\begin{array}{c}\text { Final } \\
\text { value of } \\
\text { COD } \\
\text { (mg/l) }\end{array}$ & $\begin{array}{c}\text { Removal } \\
\text { efficiency } \\
\text { of COD in } \\
\text { \% }\end{array}$ \\
\hline 1 & 1400 & 1034 & 34.87 \\
\hline 2 & 1400 & 1038 & 47.8 \\
\hline 3 & 1400 & 1045 & 38.9 \\
\hline 4 & 1400 & 1065 & 85.43 \\
\hline 5 & 1400 & 1055 & 85.43 \\
\hline 6 & 1400 & 1055 & 74.73 \\
\hline 7 & 1400 & 1080 & 91.6 \\
\hline 8 & 1400 & 843 & 95 \\
\hline
\end{tabular}

At the HRT of $8 \mathrm{hrs}$, maximum Total suspended solids were removal of $95 \%$ was obtained. At this first HRT it was about $34 \%$ and then there is up and raise this is shown in the graph.

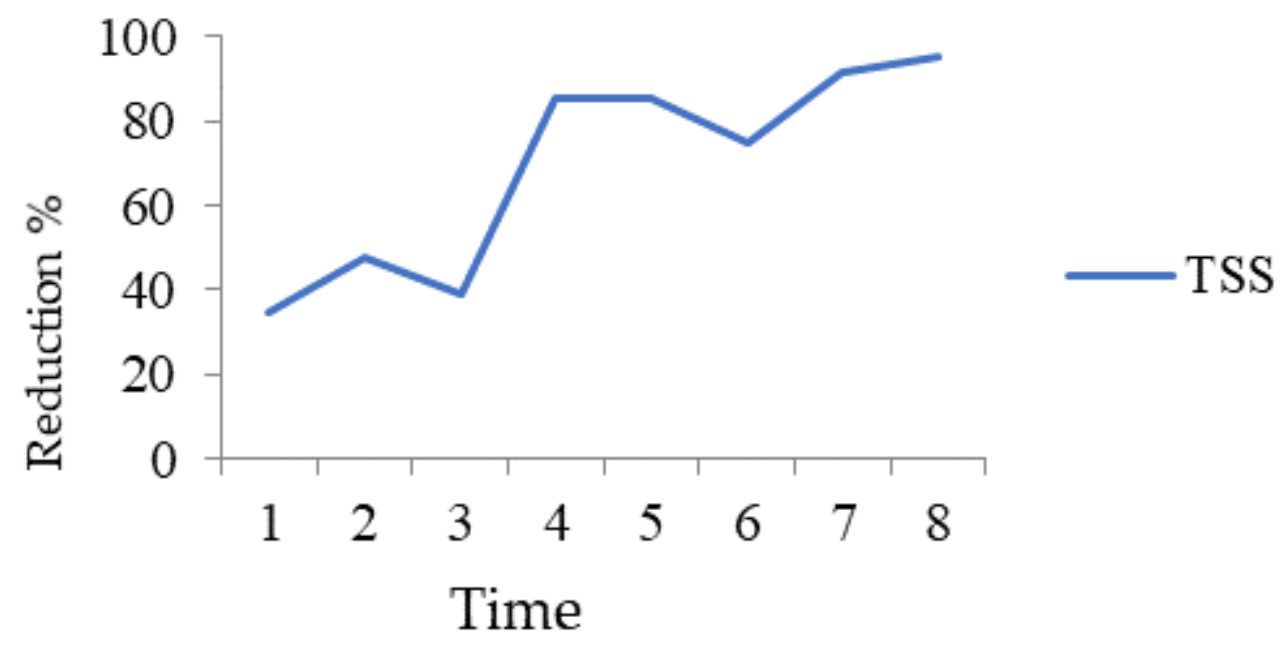

Figure 4: Graph of TSS removal efficiency for $8 \mathrm{hrs}$. 
It can be observed that the removal efficiency of both BOD and TSS increases with increasing hydrogen peroxide dosage up to the point of maximum.

\subsection{Effect of pH on COD removal}

A serious of batch experiments were conducted to investigate the effect of $\mathrm{pH}$ on $\mathrm{COD}$ removal by maintaining $\mathrm{H}_{2} \mathrm{O}_{2}$ concentration and catalyst $\left(\mathrm{Fe}^{2+}\right)$ dosage as $20 \mathrm{ml} / 1$ and $5 \mathrm{~g} / \mathrm{l}$ respectively and $\mathrm{UV}$ power as $36 \mathrm{Watts}^{\mathrm{H}}$ values were varied in the range of 2 to 9 .

Table 3: pH Effect on COD Removal

\begin{tabular}{|c|c|c|c|}
\hline $\mathbf{p H}$ & $\begin{array}{c}\text { Initial value } \\
\text { of COD } \\
(\mathbf{m g} / \mathbf{l})\end{array}$ & $\begin{array}{c}\text { Final value } \\
\text { of COD } \\
(\mathbf{m g} / \mathbf{l})\end{array}$ & $\begin{array}{c}\text { Removal } \\
\text { efficiency in } \\
\text { \% }\end{array}$ \\
\hline 2 & 1600 & 2389 & 61.46 \\
\hline 3 & 1600 & 876.4 & 80.1 \\
\hline 5 & 1600 & 2867 & 53.75 \\
\hline 7 & 1600 & 4986 & 19.58 \\
\hline 9 & 1600 & 1976 & 8.87 \\
\hline
\end{tabular}

It was observed that maximum COD of $80 \%$ was achieved at $\mathrm{P}^{\mathrm{H}}$ at 3 and COD and BOD removal decreased with increase in pH.It can be attributed that in alkaline environment, $\mathrm{H}_{2} \mathrm{O}_{2}$ is unstable and easily decomposes to produce water and oxygen rather than forming hydroxyl radicals most directly however at values higher than 4 ferrous ions easily form ferric ions which have a tendency to produce ferric hydroxy complexes variation of percentage COD with respect to $\mathrm{P}^{\mathrm{H}}$ is shown in figure.

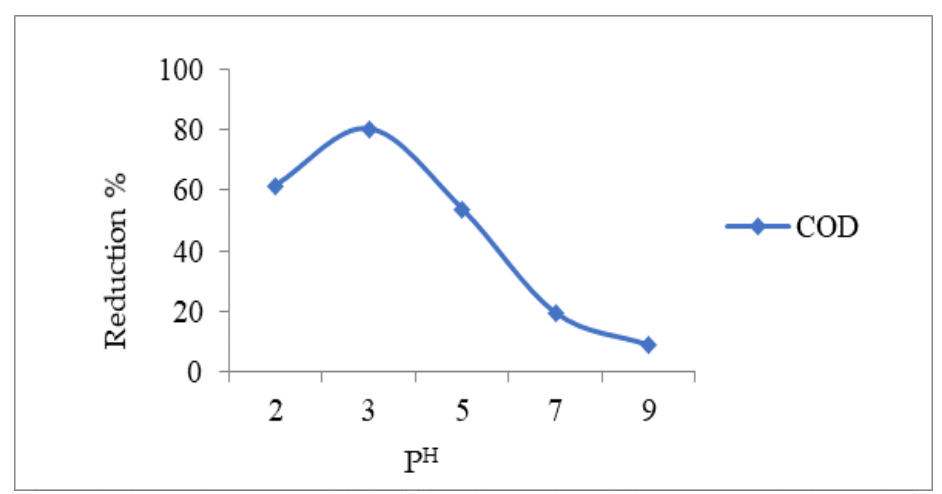

Figure 5: Graph of pH effect on COD removal for $8 \mathrm{hrs}$.

\subsection{Effect of pH on TSS Removal}

The $\mathrm{P}^{\mathrm{H}}$ during the experiment was 10 and it was adjusted to various $\mathrm{pH}$ condition. A serious of batch experiments were conducted to investigate the effect of $\mathbf{p H}$ on TSS removal by maintaining $\mathrm{H}_{2} \mathrm{O}_{2}$ concentration and catalyst $\left(\mathrm{Fe}^{2+}\right)$ dosage as $20 \mathrm{ml} / \mathrm{l}$ and $5 \mathrm{~g} / \mathrm{l}$ respectively and UV power as 36 watts. $\mathrm{pH}$ values were varied in the range of 2 to 9.

Table 4: pH Effect on TSS Removal

\begin{tabular}{|c|c|c|c|}
\hline $\mathbf{p H}$ & $\begin{array}{c}\text { Initial value } \\
\text { of TSS } \\
(\mathbf{m g} / \mathbf{l})\end{array}$ & $\begin{array}{c}\text { Final value } \\
\text { of TSS } \\
\text { (mg/l) }\end{array}$ & $\begin{array}{c}\text { Removal } \\
\text { efficiency in } \\
\text { \% }\end{array}$ \\
\hline 2 & 1400 & 1670 & 40.63 \\
\hline
\end{tabular}




\begin{tabular}{|c|c|c|c|}
\hline 3 & 1400 & 1740 & 74.38 \\
\hline 5 & 1400 & 1643 & 38.6 \\
\hline 7 & 1400 & 1660 & 40.34 \\
\hline 9 & 1400 & 1760 & 80.02 \\
\hline
\end{tabular}

Similarly, on further process there was a greater TSS removal. Nearly $80 \%$ of total dissolved solids was removed in the wastewater by adjusting various $\mathrm{pH}$

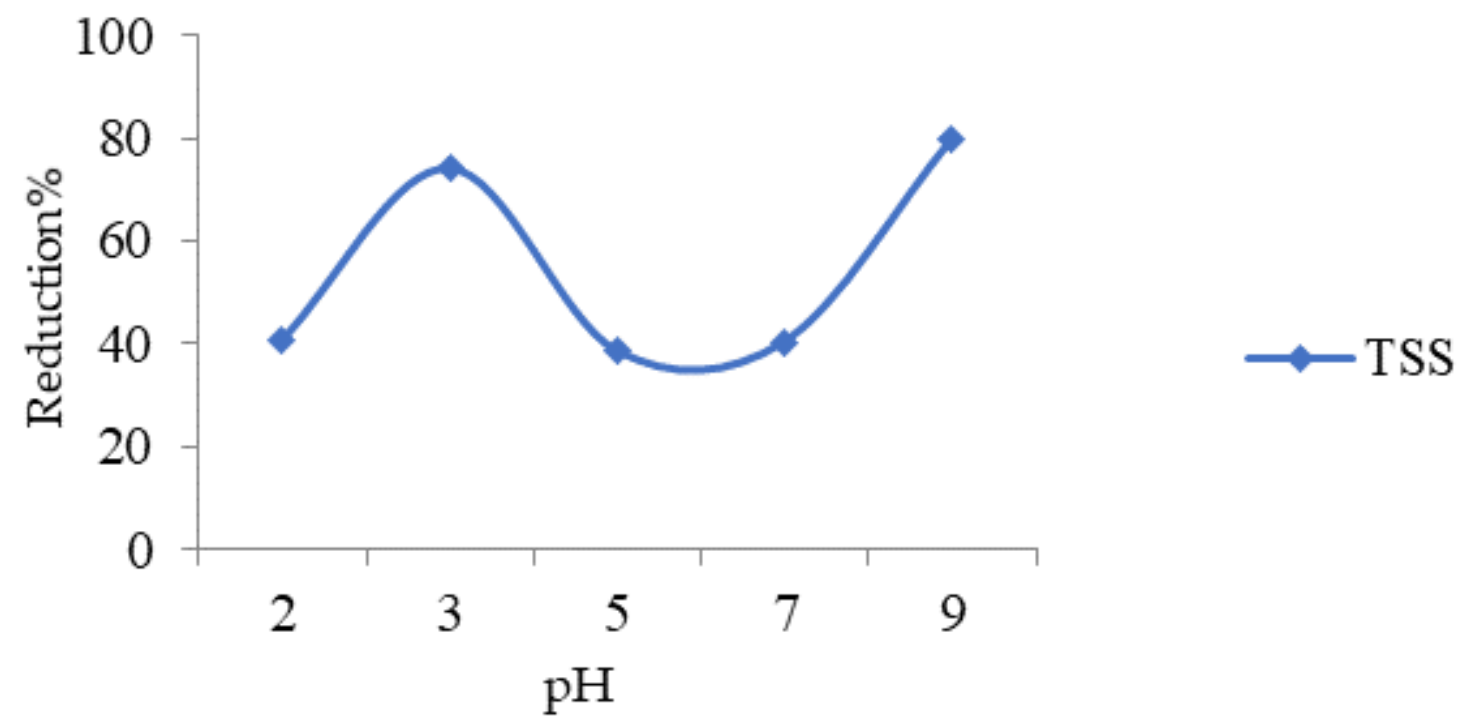

Figure 6: Graph of pH effect on TSS removal for $8 \mathrm{hrs}$.

\subsection{Effluvium Characteristic before and after Treatment}

Table 5: Effluvium Comparison

\begin{tabular}{|l|c|c|}
\hline \multicolumn{1}{|c|}{ Property } & Before & After \\
\hline $\mathrm{pH}$ & 10 & 5 \\
\hline Colour & 600 & 300 \\
\hline BOD & $2066 \mathrm{mg} /$ litre & $200 \mathrm{mg} / 1$ \\
\hline COD & $6200 \mathrm{mg} /$ litre & $700 \mathrm{mg} / 1$ \\
\hline Turbidity & $785 \mathrm{NTU}$ & $30 \mathrm{NTU}$ \\
\hline $\begin{array}{l}\text { Total suspended } \\
\text { solids }\end{array}$ & $1400 \mathrm{mg} /$ litre & $450 \mathrm{mg} / \mathrm{litre}$ \\
\hline chloride & $1000 \mathrm{mg} /$ litre & $150 \mathrm{mg} /$ litre \\
\hline
\end{tabular}

The comparison between Tannery effluvium has been analyzed before and after treatment it shows the drastic fall in its concentration after the treatment. From the graph we can see that the reactor has achieved the maximum tannery effluvium removal efficiency of $95 \%$. It is greater than all other methods avail for the removal of tannery effluvium. [13] 


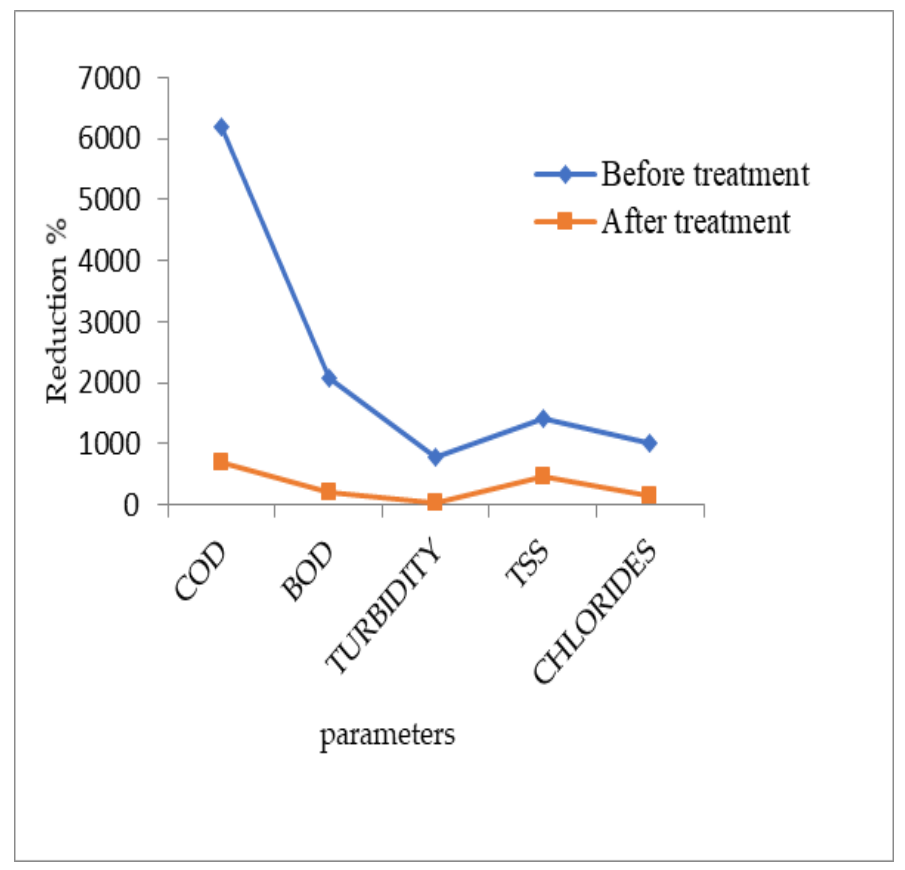

Figure 7: Comparison of parameters

\section{CONCLUSIONS}

The Radiant- Fenton Reactor has established as a well proven compact reactor for effluvium treatment. It has been used for small as well as large plant. Radiant-Fenton Reactor are capable of removing COD effectively. The following conclusion might be drawn as a result of application of a Radiant-Fenton reaction which indicate that, the optimum irradiation time was a minute at $\mathrm{P}^{\mathrm{H}} 3$, the dose of $20 \mathrm{ml} / 1$ of $\mathrm{H}_{2} \mathrm{O}_{2}$ and $5 \mathrm{~g} / \mathrm{l}$ of $\mathrm{Fe}^{2+}$. Under these conditions $80 \%$ COD removal was obtained. The application of Radiant-Fenton oxidation process in tannery effluvium treatment technology is an efficient method for the decomposition of pollutants present in it and can be used successfully as a preliminary stage preceding biological treatment. For higher removal efficiency one of the solutions is to use two stage process radiant Fenton reaction and biological methods. It is necessary to check the reaction with respect to the large amount of various type of effluvium and find proper relation which enables the quick optimization of the process with respect to the changing input parameters of the effluvium subjected to treatment. Thus, this type of advanced treatment consisting of Radiant-Fenton reactors is viable technique for treating industrial as well as domestic effluvium.

\section{REFERENCES}

1. Ay, Filiz, Ebru Cokay Catalkaya, and Fikret Kargi. "A statistical experiment design approach for advanced oxidation of Direct Red azo-dye by photo-Fenton treatment." Journal of Hazardous Materials, vol.162, no. 1, pp. 230-236, Feb.2009.

2. Babuponnusami, Arjunan, and Karuppan Muthukumar. "A review on Fenton and improvements to the Fenton process for wastewater treatment." Journal of Environmental Chemical Engineering, vol.2, no. 1, pp. 557-57,Mar.2014.

3. Cooman, K., M. Gajardo, J. Nieto, C. Bornhardt, and G. Vidal. "Tannery wastewater characterization and toxicity effects on Daphnia spp." Environmental Toxicology: An International Journal, vol.18, no. 1, pp. 45-51, Jan.2003

4. Dutta, K., Mukhopadhyay, S., Bhattacharjee, S., \& Chaudhuri, B. (2001). Chemical oxidation of methylene blue using a Fenton-like reaction. Journal of hazardous materials, 84(1), 57-71.

5. Ebrahiem, E. E., Al-Maghrabi, M. N., \& Mobarki, A. R. (2017). Removal of organic pollutants from industrial wastewater by 
applying photo-Fenton oxidation technology. Arabian Journal of Chemistry, vol,10, S1674-S1679.

6. Elmorsi, T. M., Riyad, Y. M., Mohamed, Z. H., \& El Bary, H. M. A. (2010). Decolorization of Mordant red 73 azo dye in water using H2O2/UV and photo-Fenton treatment. Journal of Hazardous Materials, 174(1-3), 352-358.

7. Sivakumar, S., N. Ranjithkumar, and S. Ragunathan. "Design and development of down draft wood gasifier." International Journal of Mechanical Engineering 2.2 (2013): 1-10.

8. Garole, V. J., Choudhary, B. C., Tetgure, S. R., Garole, D. J., \& Borse, A. U. (2018). Detoxification of toxic dyes using biosynthesized iron nanoparticles by photo-Fenton processes. International Journal of Environmental Science and Technology, 15(8), 1649-1656.

9. Hasegawa, M. C., Daniel, J. F. D. S., Takashima, K., Batista, G. A., \& da Silva, S. M. (2014). COD removal and toxicity decrease from tannery wastewater by zinc oxide-assisted photocatalysis: a case study. Environmental technology, 35(13), 1589-1595.

10. Qashqaei, Amir, and Ramin Ghasemi Asl. "Numerical Modeling And Simulation Of Copper Oxide Nanofluids Used In Compact Heat Exchangers." International Journal of Mechanical Engineering, 4 (2), 18 (2015).

11. Mahdad, F., Younesi, H., Bahramifar, N., \& Hadavifar, M. (2016). Optimization of Fenton and photo-Fenton-based advanced oxidation processes for post-treatment of composting leachate of municipal solid waste by an activated sludge process. KSCE Journal of Civil Engineering, 20(6), 2177-2188.

12. Yemelyanova, V. S., et al. "Modified aluminosilicate catalysts based on cenospheres of power plants for processing fuel oil into light fractions." International Journal of Mechanical and Production Engineering Research and Development 9.4 (2019): 1079-1086.

13. Seibert, D., Diel, T., Welter, J. B., de Souza, A. L., Módenes, A. N., Espinoza-Quiñones, F. R., \& Borba, F. H. (2017). Performance of photo-Fenton process mediated by $\mathrm{Fe}$ (III)-carboxylate complexes applied to degradation of landfill leachate. Journal of environmental chemical engineering, 5(5), 4462-4470.

14. Silva, T. F., Fonseca, A., Saraiva, I., Boaventura, R. A., \& Vilar, V. J. (2016). Scale-up and cost analysis of a photo-Fenton system for sanitary landfill leachate treatment. Chemical Engineering Journal, 283, 76-88.

15. Sivagami, K., Sakthivel, K. P., \& Nambi, I. M. (2018). Advanced oxidation processes for the treatment of tannery wastewater. Journal of environmental chemical engineering, 6(3), 3656-3663.

16. ABDULLAH, HUSSAIN ISMAIL, and Lamyaa Jabbar Abbas. "Photosynthesis of Chromium oxide Nanoparticles from chromium complexes." International Journal of Applied, Physical and Bio-Chemistry Research (IJAPBCR) 7 (2017): 1-8.

17. Tavares, M. G., Santos, D. H. D. S., Torres, S. J. A., Pimentel, W. R. O., Tonholo, J., \& Zanta, C. L. D. P. E. S. (2016). Efficiency and toxicity: comparison between the Fenton and electrochemical processes. Water Science and Technology, 74(5), $1143-1154$.

18. Vidal, G., Nieto, J., Mansilla, H. D., \& Bornhardt, C. (2004). Combined oxidative and biological treatment of separated streams of tannery wastewater. Water Science and Technology, 49(4), 287-292.

19. Vilardi, G., Ochando-Pulido, J. M., Stoller, M., Verdone, N., \& Di Palma, L. (2018). Fenton oxidation and chromium recovery from tannery wastewater by means of iron-based coated biomass as heterogeneous catalyst in fixed-bed columns. Chemical Engineering Journal, 351, 1-11. 